\title{
In vitro inhibition of thrombin generation by sulfated polysaccharides from the red seaweed Halymenia sp. delivery on the Ceará coast, Brazil
}

\section{Inibição in vitro de geração de trombina por polissacarídeos sulfatados da alga marinha vermelha Halymenia sp. arribada na costa cearense, Brasil}

José Ariévilo Gurgel Rodrigues ${ }^{1}$, Priscila Gomes Barcellos ${ }^{1}$, Norma Maria Barros Benevides $^{2}$, Ana Maria Freire Tovar ${ }^{1}$ \& Paulo Antônio de Souza Mourão ${ }^{1}$

${ }^{1}$ Instituto de Bioquímica Médica, Universidade Federal do Rio de Janeiro - UFRJ

${ }^{2}$ Departamento de Bioquímica e Biologia Molecular, Universidade Federal do Ceará - UFC

*Email: arieviloengpesca@yahoo.com.br

Recebido: 18 de outubro de 2016/ Aceito: 20 de abril de 2018 / Publicado: 8 de dezembro de 2017

\begin{abstract}
Anticoagulant potential of Halymenia red seaweeds sulfated polysaccharides (SPs) to act as inhibitors of thrombin generation (TG) is unknown. This study aimed to examine the in vitro inhibition of TG by Halymenia sp. SPs. Papain incubation yielded extract $(41.6 \%)$ containing three polysaccharidic fractions (F I, F II and F III, eluted at 0.5, 0.75 and $1 \mathrm{M}$ $\mathrm{NaCl}$ ) separated by DEAE-cellulose anion-exchange chromatography, with differences among the relative proportions of sulfate (20.34-35.12\%), total sugars (30.02-62.77\%) and no traces of proteins. Procedures in $5 \%$ agarose $/ 6 \%$ polyacrylamide gel electrophoresis revealed complex glycans migrating as negatively charged components and high molecular distribution (> $100 \mathrm{kDa}$ ), respectively. These techniques, when associated with the use of stains-all, nonSPs were also suggested. Blood coagulation was modified by extract (19.6 IU mg $\mathrm{m}^{-1}$ ) and fractions (3.96, 7.88 and $2.04 \mathrm{IU}$ $\mathrm{mg}^{-1}$, respectively) dependent on the sulfation degree of the SPs using the activated partial thromboplastin time test vs. heparin (193 IU mg-1 $\mathrm{m}^{-1}$, while Haymenia sp. SPs-treated human plasma did not altered the prothrombin time. In TG continuous assay in 60-fold diluted human plasma using chromogenic substrate showed that extract and F II inhibited concentrationdependent and sulfation both intrinsic and extrinsic coagulation pathways, with $50 \%$ efficacy on cephalininduced TG already at concentrations of 4.1 and $8.3 \mu \mathrm{g}$ of extract vs. heparin that had ability to abolish TG at 20-fold lower concentration. The results reveal to a potential of the Halymenia sp. SPs obtained at a different period of the year to prevent thrombosis in vitro and opportunities to use this species in industry could be better recognized in studies future.
\end{abstract}

Keywords: Rhodophyta, sulfated glycans, chemical analyses, thrombin.
Resumo O potencial anticoagulante de polissacarídeos sulfatados (PSs) de algas marinhas vermelhas Halymeniané desconhecido para agirem como inibidores de geração de trombina (GT). Este estudo objetivou examinar a inibição in vitro de GT por PSs de Halymenia sp. Incubação com papaína rendeu extrato $(41,6 \%)$ contendo três frações polissacarídicas (F I; F II e F III, eluídas em 0,5; 0,75 e 1 $\mathrm{M}$ de $\mathrm{NaCl}$ ) separadas por cromatografia de troca-iônica (DEAE-celulose), com diferenças entre as proporções relativas de sulfato $(20,34-35,12 \%)$, açúcares totais $(30,02-$ $62,77 \%$ ) e sem traços de proteínas. Procedimentos em eletroforese em gel de agarose $(5 \%)$ / poliacrilamida $(6 \%)$ revelaram glicanos complexos migrando como componentes carregados negativamente e distribuição molecular elevada (> $100 \mathrm{kDa})$, respectivamente. Essas técnicas, quando associadas com o uso de "stains-all", foram também sugeridas polissacarídeos não-sulfatados. A coagulação sanguínea foi modificada pelo extrato (19,6 UI $\left.\mathrm{mg}^{-1}\right)$ e frações $\left(3,96 ; 7,88\right.$ e $2,04 \mathrm{UI} \mathrm{mg}^{-1}$, respectivamente) dependente do grau de sulfatação dos PSs usando o teste do tempo de tromboplastina parcial ativada vs. heparina (193 UI $\mathrm{mg}^{-1}$ ), enquanto plasma humano tratado com PSs de Halymenia sp. não alterou o tempo de protrombina. No ensaio contínuo de GT em plasma humano diluído 60 vezes usando substrato cromogênico mostrou que extrato e F II inibiram dependente de concentração e sulfatação ambas as vias da coagulação intrínseca e extrínseca, com eficácia de $50 \%$ sobre TG induzida por cefalina já em concentrações de 4,1 e $8,3 \mu \mathrm{g}$ de extrato vs. heparina que deteve habilidade para abolir GT em concentração 20 vezes menor. Os resultados revelam para um potencial dos PSs de Halymenia sp. obtidos em um período diferente do ano para prevenir trombose in vitro e oportunidades para uso dessa espécie na indústria poderia ser reconhecida melhor em futuros estudos.

Palavras-chave: Rhodophyta, glicanos sulfatados, análises químicas, trombina.

Trabalho realizado com apoio financeiro da Capes-PNPD/Faperj/CNPq/MCTIC. 


\section{Introduction}

The blood circulatory diseases and thrombotic disorders have drastically affected the lifestyle of the people in the last decades, especially in developed countries. In conventional clinical therapy primary requires anticoagulants to modulate the homeostatic dysfunctions to allow normal circulation to the different organ systems of the body (Nader et al., 2001). Unfractionated heparin (UHEP), which has specific pentasaccharide sequence with high antithrombin affinity does not found in other anticoagulant sources (Mourão, 2015), is the routinely anticoagulant drug used to treat and prevent deep vein thrombosis, but the production this therapeutic agent is very limited from animal tissues and has elevated risk factors associated to its clinical administration (mainly bleeding and UHEP-induced thrombocytopenia) (Nader et al., 2001).

Seaweeds (marine macroalgae) arise as safer natural anticoagulants because they have high contents of extracellular matrix sulfated polysaccharides (SPs) (Pomin \& Mourão, 2008; Rodrigues, Torres, Alencar, Sampaio \& Farias, 2009a; Mourão, 2015), without presenting important toxicity and reduced risks of contamination by viral particles (Leite et al., 1998), although varying among species and ecophysiological growth conditions of the algae (Cardozo et al., 2007). These SPs have complex and heterogeneous nature, with molecular masses of more than $100 \mathrm{kDa}$ and highly charged (ester sulfate groups, $\mathrm{S}=\mathrm{O}$ ) (Pomin, 2012). Their chemical structures vary among phyla and are overall classified into three polymeric classes 1) sulfated galactans (agar and carrageenan) which are express in Rhodophyceae (Kloareg \& Quatrano, 1988; Quinderé et al., 2014; Mourão, 2015); 2) fucans or fuicodan which are found in Phaeophyceae (Pomin \& Mourão, 2008; Pomin, 2012; Zhang et al., 2014); and 3), while in Chlorophyceae, sulfated heteropolysaccharides are synthesized showing the greatest variations in terms of structural composition (Pomin \& Mourão, 2008; Wang, Wang, Wu \& Liu, 2014). On a basis of evolution and phylogenetic distribution, SPs also occur in a great variety of organisms, such as in marine angiosperm Ruppia maritima (Aquino, Landeira-Fernandez, Valente, Andrade \& Mourão, 2005), freshwater plant Eicchornia crassipes (Dantas-Santos et al., 2012) and edible mushroom Armillariella lellea (Chang, Lur, Lu \& Cheng, 2013).

The biological effects of the seaweeds SPs are widely known on the blood coagulation, when tested in in vivo and/or in vitro experimental systems for the discovery of alternative tools to clinically-used drugs in the treatment of diseases (Quinderé et al., 2014; Mourão, 2015), and in other systemic dysfunctions, such as on chemically-induced inflammatory processes (Pomin, 2012; Rodrigues et al., 2012). In particular on the haemostatic system, they frequently act as anticoagulants by inhibiting of the intrinsic and/or extrinsic coagulation pathways, when evaluated by measuring the clotting time using the activated partial thromboplastin time (APTT) and prothrombin time (PT) tests, respectively. The anticoagulant potential of these molecules have positive correlation with both sulfate content and molecular size to extend the normal coagulation in vitro (Rodrigues, Torres, Alencar, Sampaio \& Farias, 2009a; Pomin, 2012; Mourão, 2015).

However, the search for algae anticoagulant SPs as substitutes to UHEP cannot be only restricted to traditional coagulation models due to their limited accuracy to reflect the phases of clot formation; therefore, with low precision for measure only an amount of 5\% thrombin generated in a plasma sample (Castoldi \& Rosing, 2011). From these experimental limitations, thrombin generation (TG)-based coagulation protocols have been introduced in recent times, not only as novel approaches to predict the coagulability of the plasma after in vitro activation to better postulate the clinical events related to hemostasis (bleeding and thrombosis) (Castoldi \& Rosing, 2011), but also to develop alternative anticoagulants from different origins. For example, for the native SPs (fucosylated chondroitin sulfate) obtained from the Brazilian sea cucumber Ludwigothurea grisea, Mourão et al. (2001) found in vitro modulatory effect on TG after induction by both contact-activated and thromboplastin-activated systems. SPs isolated from the seaweeds Ecklonia kurome (Ochrophyta) (Nishiro, Fukuda, Nagumo, Fujihara \& Kaji, 1999) and Botryocladia occidentalis (Rhodophyta) (Glauser et al., 2009) inhibited TG by the prothrombinase complex. It was assessed by Zhang et al. (2014) both pro- and anticoagulant effects of the fucoidan derived from the brown seaweed Fucus vesiculosus using calibrated automated thrombography. Recently, a native SPs fraction and its various chemically (HCl-treatment)-modified products, from the red seaweed Acanthophora muscoides, were capable of abolishing an in vitro TG system induced by intrinsic coagulation pathway using continuous detection assay (Rodrigues et al., 2016). In current reports, Salles et al. (2017) and Rodrigues et al. (2017) isolated SPs from the skin of Nile tilapia (Oreochromis niloticus) and from the red seaweed Gracilaria birdiae, respectively, displaying in vitro TG inhibitions.

The genus Halymenia C. Agardh (1817) comprises a taxonomic interrelationship among species of red seaweeds (Halymeniales, Florideophyceae) still not understood within of the phylum Rhodophyta. Algae from this genus have attracted attention not only as sources of carrageenans (the most common types of 
commercial carrageenans are the co-polymers kappa, iota and lambda (Silva et al., 2010; Prajapati, Maheriya, Jani \& Solanki, 2014)) for the hydrocolloid industry worldwide due to their potentially useful thickening and gelling abilities in food preparations (Lail, Li \& Li, 1994; Fenoradosoa et al., 2009), but also in chemotaxonomy (Rodrigues \& Farias, 2009), animal healthy (Rodrigues, Júnior, Lourenço, Lima \& Farias, 2009b) and pharmacological bioprospection (Rodrigues, Torres, Alencar, Sampaio \& Farias, 2009a; Amorim, Rodrigues, Holanda, Mourão \& Benevides, 2011; Rodrigues et al., 2011; Rodrigues et al., 2012). Exploring anticoagulant SPs (Halymenia species) using in vitro TG tests has not been still reported.

The tropical red seaweed Halymenia sp. represents a biomass available on the shores of Northeastern coast of Brazil to obtain and evaluate the biotechnological potential of its matrix SPs (Rodrigues \& Farias, 2009; Rodrigues et al., 2012). Considering the mentioned, the aim of this study was to analyze the physicalchemical characteristics of the cell-wall SPs of this algal species by combination of agarose and polyacrylamide gel electrophoresis and sequential staining with toluidine blue and stains-all. The anticoagulant potential was also examined by testing the clotting time using both in vitro APTT and PT assays. The anti-clotting dynamic of the SPs was further assessed using a TG continuous model in 60-fold diluted human plasma to verify their capacities to prevent thrombosis in vitro.

\section{Material and Methods}

\section{MARINE ALGA SAMPLE COLLECTION AND STRAIN IDENTIFICATION}

The delivered Brazilian samples of Halymenia sp. were manually collected in June 2010 from tidal region at Flecheiras beach (Trairí, Ceará state) as described (Rodrigues et al., 2012). Collected alga was transported (in plastic bags) to the Carbohydrates and Lectins laboratory (CarboLec), Federal University of Ceará, washed with distillated water to remove salt and sand, followed by dehydration of the material at forced-air drying oven $\left(3 \mathrm{~h}, 60^{\circ} \mathrm{C}\right)$ prior to crude SP extraction. The identification of the algal strain samples as Halymenia sp. was confirmed by $\mathrm{PhD}$. José Ariévilo Gurgel Rodrigues from the Department of Fishing Engineering of the Federal University of Ceará, Brazil. A voucher specimen was then deposited in the Herbarium Prisco Bezerra of the Department of Biological Sciences, Federal University of Ceará, Brazil. The biotechnological investigations of the Halymenia sp. SPs were carried out at the Connective Tissue laboratory, Federal University of Rio de Janeiro, Brazil.

SPS EXTRACTION AND FRACTIONATION ON DEAE-CELLULOSE ANION-EXCHANGE COLUMN

Two grams of the dehydrated tissue of Halymenia sp. were cut into small pieces and subjected to papain digestion $\left(60^{\circ} \mathrm{C}, 24 \mathrm{~h}\right)$ in $100 \mathrm{mM}$ sodium acetate buffer $(\mathrm{pH} 5.0)$ containing cysteine and EDTA (both 5 $\mathrm{mM}$ ), as previously published elsewhere (Rodrigues et al., 2012). The yield of the crude extract was calculated as percentage (\%) from the dehydrated algal matter. For the fractionation, a sample of the crude extract $(20 \mathrm{mg}$ ) was dissolved in $10 \mathrm{~mL}$ of $50 \mathrm{mM}$ sodium acetate buffer (pH 5.0) and applied to a DEAEcellulose anion-exchange chromatography column $(1.2 \times 12 \mathrm{~cm})$ equilibrated with the same buffer. The fractionation was conducted using a stepwise of $\mathrm{NaCl}$ (from 0 to $1 \mathrm{M} \mathrm{NaCl}$ at $0.25 \mathrm{M}$ intervals in the same buffer). Fractions of $2.5 \mathrm{~mL}$ were collected and analyzed for SPs using the metachromatic assay $\left(\mathrm{A}_{525 \mathrm{~mm}}\right)$ containing dimethymethylene blue with an Amersham Bioscience Ultrospec 3100 spectrosphotometer at $525 \mathrm{~nm}$ (Farndale, Buttle, \& Barrett, 1986). The metachromatic fractions were further dialyzed and freeze dried, and the yield was calculated as percentage (\%) from the raw sample applied on DEAE-cellulose column. Integrated metachromatic area (IMA) of the fractions was also calculated as an additional parameter for sulfate using a Statistical Analysis Software version 8.0 Origin Program

(Rodrigues et al., 2012).

\section{CHEMICALS ANALYSES}

Total sugars content was estimated by phenol-sulfuric acid analysis using D-galactose as the standard on tube method using an Amersham Bioscience Ultrospec 3100 spectrosphotometer (Dubois, Gilles, Hamilton, Rebers \& Smith, 1956). After acid hydrolysis of the SPs samples ( $1 \mathrm{~mL} \mathrm{HCl}$ for $5 \mathrm{~h}$ at $\left.100^{\circ} \mathrm{C}\right)$, sulfate was measured by the $\mathrm{BaCl}_{2}$-gelatin method (Dodgson \& Price, 1962). The contaminant proteins content was measured by Bradford assay (1976), using bovine serum albumin to construct the standard curve. 


\section{PHYSICAL-CHEMICAL CHARACTERIZATION BY AGAROSE / POLYACRYLAMIDE GEL ELECTROPHORESES}

The crude extract and its SPs fractions eluted in the DEAE-cellulose column were analyzed by $0.5 \%$ agarose gel electrophoresis according to Dietrich \& Dietrich (1976). Samples of each SPs fraction (25 $\mu \mathrm{g})$ were applied to a gel and run for $1 \mathrm{~h}$ at $110 \mathrm{~V}$ in $0.05 \mathrm{M} 1.3$ diaminopropane-acetate buffer (pH 9.0). SPs on gel were fixed with $0.1 \% \mathrm{~N}$-cetyl- $\mathrm{NN}-\mathrm{N}$-trimethyl-ammonium bromide solution. After $24 \mathrm{~h}$, the gel was dried and stained with $0.1 \%$ toluidine blue and discolored with an acetic acid:absolute ethanol:distilled water solution (0.1:0.45:0.45). The degree of polydispersion of the SPs was examined by comparison with the electrophoretic mobility of standard glycosaminoglycans chondroitin-6-sulfate (C-6-S), heparin sulfate (HS) and dermatan sulfate (DS).

To analyze the molecular mass distribution, the crude extract and its SPs fractions eluted in the DEAEcellulose column were also subjected to $6 \%$ polyacrylamide gel electrophoresis according to Rodrigues et al. (2016). Samples of each SPs fraction $(15 \mu \mathrm{g})$ were applied to a $6 \% 1$-mm-thick polyacrylamide slab gel in $0.02 \mathrm{M}$ TRIS-HCl, $\mathrm{pH} 8.6$, and run for $60 \mathrm{~min}$ at $500 \mathrm{~mA}$. After $24 \mathrm{~h}$, the gel was dried and stained with $0.1 \%$ toluidine blue and discolored with $0.1 \%$ acetic acid. The molecular masses of the SPs were estimated by comparison with the electrophoretic mobility of standard glycosaminoglycans chondroitin-4-sulfate (C-4-S, $40 \mathrm{kDa}$ ), chondroitin-6-sulfate (C-6-S, $~ 60 \mathrm{kDa}$ ) and dextran sulfate (Dex, $\sim 8 \mathrm{kDa})$.

From these electrophoretic procedures, the detection of nonSPs from the isolated polymer samples on both agarose / polyacrylamide gels was also conducted by associated staining with Stains-All, as demonstrated for animal-matrix glycosaminoglycans (Volpi \& Maccari, 2002; Salles et al., 2017).

\section{IN VITRO COAGULATION ASSAYS}

\section{BLOOD SAMPLES}

Coagulation analyses were conducted using venous blood samples collected in citrated Vacutainer tubes containing 3.2\% sodium citrate from 10 different donors (University Hospital Clementino Fraga Filho, Federal University of Rio de Janeiro), followed by centrifugation at $2000 \times g$ for 15 min prior to tests. Normal citrated human plasma aliquots of $1 \mathrm{~mL}$ were frozen and stored at $-70^{\circ} \mathrm{C}$ until use

(Rodrigues et al., 2017).

\section{ACTIVATED PARTIAL THROMBOPLASTIN TIME (APTT) AND PROTHROMBIN (PT) TESTS}

Fractions were assessed by both in vitro APTT and PT tests, using normal citrated human plasma (10 different donors, University Hospital Clementino Fraga Filho, FURJ) according to the manufacturers' specifications, for measure a possible anti-clotting effect in a coagulometer Amelung KC4A before of the in vitro TG assay.

For the APTT assay, a mixture of $100 \mu \mathrm{L}$ of plasma and different concentrations of SPs $\left(0-1 \mathrm{mg} \mathrm{mL}^{-1}\right)$ were incubated with $100 \mu \mathrm{L}$ of APTT reagent (kaolin bovine phospholipid reagent). After 2 min of incubation at $37^{\circ} \mathrm{C}, 100 \mu \mathrm{L}$ of $25 \mathrm{mM} \mathrm{CaCl}_{2}$ was added to the mixtures, and the clotting time was recorded.

Regarding the PT assay, a mixture of $100 \mu \mathrm{L}$ of plasma and concentration of SPs $\left(1 \mathrm{mg} \mathrm{mL}^{-1}\right)$ was incubated for $1 \mathrm{~min}$ at $37^{\circ} \mathrm{C}$. After that, $100 \mu \mathrm{L}$ of PT reagent was added to the mixtures, and the clotting time was recorded using same coagulation equipment.

UHEP with 193 international units per $\mathrm{mg}\left(\mathrm{IU} \mathrm{mg} \mathrm{m}^{-1}\right.$ ) of polysaccharide was used as the standard on both tests. All the tests were performed in triplicate.

\section{TG-BASED ASSAY}

A more detailed analysis on in vitro coagulation was conducted with crude extract and a polysaccharidic fraction (named F II) that proved highest SPs yield. The assay was performed according to Rodrigues et al. (2016) in a microplate format, containing: $10 \mu \mathrm{L}$ of cephalin (contact-activator system) or thromboplastin $\left(830 \mu \mathrm{g}\right.$ well-plate ${ }^{-1}$, tissue factor-activator system) $+30 \mu \mathrm{L}$ of $0.02 \mathrm{M}$ Tris HCl/PEG-buffer $(\mathrm{pH} 7.4)+10$ $\mu \mathrm{L}$ of SPs (Halymenia sp. Extract / Fraction F II: 0, 4.1, 41.6 and $83.3 \mu \mathrm{g}$ well-plate ${ }^{-1}$ or UHEP: 2 or $4 \mu \mathrm{g}$ well-plate $\left.{ }^{-1}\right)+60 \mu \mathrm{L}$ of a solution containing $20 \mathrm{mM} \mathrm{CaCl} 2$ and $0.33 \mathrm{mM}$ chromogenic substrate S2238 $\left(10: 50\right.$ ratio, v:v). The in vitro reaction was triggered at $37^{\circ} \mathrm{C}$ by addition of normal human plasma (diluted 60-fold well-plate $\left.{ }^{-1}\right)(10 \mu \mathrm{L})$, and the absorbance $(405 \mathrm{~nm})$ was recorded for 60 min (Plate reader Thermomax, America Devices). The in vitro inhibitory response of TG by Halymenia sp. SPs was determined by 
Acta of Fisheries and Aquatic Resources

peak thrombin (PTh) and time to peak (TPeak). Graphics were processed using Statistical Analysis Software version 8.0 Origin Program.

\section{EXPRESSION OF DATA AND STATISTICAL ANALYSES}

Clotting times automatically recorded from the APTT and PT assays were subsequently plotted to Statistical Analysis Software version 8.0 Origin Program. Data were expressed as mean \pm S.E.M. $(n=3)$ and analyzed using one-way ANOVA with subsequent post hoc analyses (Tukey's test) for comparison among test samples. Values indicating $\mathrm{p}<0.05$ were considered as significant.

\section{Results and Discussion}

In this study, the dehydrated raw matter of Halymenia sp. was subjected to papain incubation to obtain wall-matrix SPs. After the drying procedure, a crude SP extraction yield of $41.60 \%$ was obtained to be similar (46\%) to this same algal species from a previous report of Rodrigues et al. (2012), who previously applied two drying methods (freeze-drying or forced-air drying oven) revealing an important difference in yield between them of $19.05 \%$. Highly significant differences in yield of Halymenia species SPs (from 15 to $47.14 \%$ ) occur depending on the extraction technique (Fenoradosoa et al., 2009; Rodrigues, Torres, Alencar, Sampaio \& Farias, 2009a; Amorim, Rodrigues, Holanda, Mourão \& Benevides, 2011).

The compositional analysis of sulfate and total sugars of the Halymenia sp. crude SP showed levels of 35.3 and $61.4 \%$, respectively. These values were in concordance to the crude SPs (17.89-33.38\% sulfate and 60.26-64.50\% total sugars) extracted from commercially-important carragenophytes (Silva et al., 2010) and other Halymenia species (44-53.8\% sulfate and 45\% total sugars) (Lail, Li \& Li, 1994; Fenoradosoa et al., 2009; Amorim, Rodrigues, Holanda, Mourão \& Benevides, 2011).

On the basis of the proteins analysis, there was no contamination from the analyzed raw sample (Rodrigues et al., 2011; Rodrigues et al., 2016), since significant levels of proteins can occur in the seaweeds cell-wall (Kloareg \& Quatrano, 1988; Pomin \& Mourão, 2008; Amorim, Rodrigues, Holanda, Mourão \& Benevides, 2011) influencing on the quality of the SPs for their use as food additives in the phycocolloid industry (Prajapati, Maheriya, Jani \& Solanki, 2014; Paula et al., 2015). Collectively, results implied that the Halymenia sp. crude SP showed similar composition during comparisons with the commercial SPs (Silva et al., 2010; Prajapati, Maheriya, Jani \& Solanki, 2014).

\section{ANALYSIS OF THE SPS BY DEAE-CELLULOSE CONTRASTS WITH PREVIOUSLY PUBLISHED FINDINGS}

Anion-exchange chromatography on a DEAE-cellulose column was employed for the Halymenia sp. crude SP separation, and the representative profile is shown in figure 1.

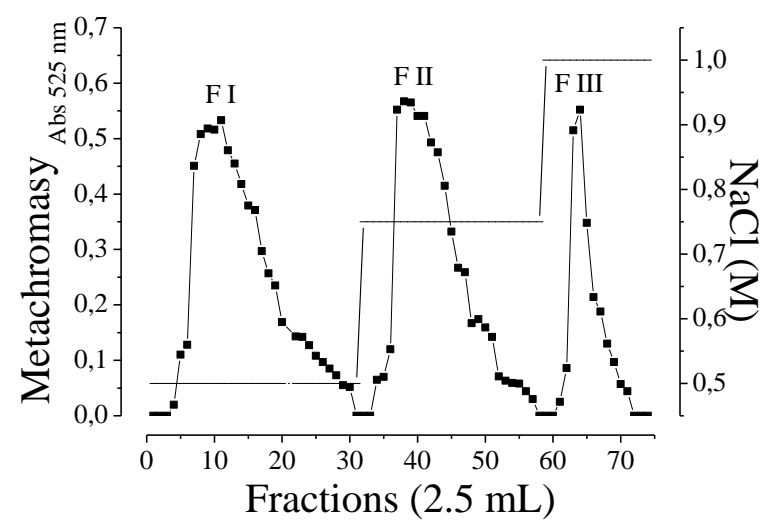

Figure 1. Separation of the SPs from Halymenia sp. by DEAE-cellulose. Fractions were collected and checked by metachromasy using 1,9-dimethylmethylene blue (-1-). (-) $\mathrm{NaCl}$ concentration.

On elution with increasing molarities of $\mathrm{NaCl}$, the matrix SPs showed three major fractions (F I, F II and F III) at $0.5,0.75$ and $1 \mathrm{M}$ of $\mathrm{NaCl}$, respectively, according to the metachromasy assay produced by marine glycans (Rodrigues et al., 2011; Rodrigues etal., 2012; Rodrigues et al., 2017), as a result of the presence of sulfate groups in their chemical structures displaying complex-binding capacities (Farndale, Buttle \& Barrett, 1986). Observations did not support the profile previously found for those samples of Halymenia sp. collected from the same beach by Rodrigues et al. (2012), who fractionated its crude SP by DEAE- 
cellulose procedure, where the column-bound marine SPs were eluted stepwise with 0.5, 0.75, 1.00 and 1.25 $\mathrm{M} \mathrm{NaCl}$. The $0.75 \mathrm{M} \mathrm{NaCl}$ fraction had highest metachromasy based on test sample.

The DEAE-cellulose chromatogram exhibited fractions with pronounced peaks of absorbance almost equal among them (Figure 1), although with differences in their IMAs, whose respective values were 44.55 (F I), 40.22 (F II) and 14.45\% (F III) (Table 1). The total IMA of the fractions F I and F II, eluted with 0.5 and $0.75 \mathrm{M} \mathrm{NaCl}$, respectively, corresponded to be 1.42 -fold higher than that found in this taxon by Rodrigues et al. (2012).

Table 1. IMA, yield and composition of the SPs fractions obtained by ion-exchange chromatography (DEAE-cellulose) from the red seaweed Halymenia sp.

\begin{tabular}{|c|c|c|c|c|c|c|c|}
\hline \multirow[b]{2}{*}{ Fraction } & \multirow[b]{2}{*}{$\mathrm{NaCl}(\mathrm{M})^{\mathrm{a}}$} & \multirow[b]{2}{*}{$\mathrm{IMA}^{\mathrm{b}}$} & \multirow[b]{2}{*}{ Yield $(\%)^{\mathrm{c}}$} & \multicolumn{4}{|c|}{ Chemical analyses (\%) } \\
\hline & & & & Sulfate $^{d}$ & $\begin{array}{c}\text { Total } \\
\text { sugars }\end{array}$ & $\begin{array}{c}\text { Total } \\
\text { sugars/sulfate }^{\mathrm{f}}\end{array}$ & $\mathrm{CPs}^{\mathrm{g}}$ \\
\hline F I & 0.50 & 44.55 & 33.30 & 31.63 & 49.31 & 1.55 & * \\
\hline F II & 0.75 & 40.22 & 59.30 & 35.12 & 62.77 & 1.90 & $*$ \\
\hline F III & 1.00 & 14.45 & 6.00 & 20.34 & 30.02 & 1.47 & $*$ \\
\hline
\end{tabular}

$\mathrm{a}-\mathrm{NaCl}$ concentration; $\mathrm{b}$ - Integrated metachromatic area determined from the Statistical Analysis Software version 8.0 Origin Program; c - Yield calculated as the percentage from a sample of extract applied on DEAE-cellulose column; $\mathrm{d}$ - Dosage by Dodgson \& Price (1976)' method using $\mathrm{NaSO}_{3}$ as standard; e - Dosage by Dubois, Gilles, Hamilton, Rebers \& Smith (1956)' method using D-galactose as standard; f - Total sugars/sulfate ratio; g - Dosage by Bradford (1976)' method using bovine serum albumin (- not detected); * Not detected.

Comparing among SPs fractions, the yield and composition corroborated with the IMA values as also listed in table 1. Regarding the fractions F I and F II, eluted at the beginning of the stepwise, they accounted for more than $90 \%$ of the total SPs recovered from the column, with yield about 2 -fold higher than that obtained under same analytical condition by Rodrigues et al. (2012). While the SPs retained in the column eluted with $1.00 \mathrm{M} \mathrm{NaCl}$ (F III) showed more relatively low levels of yield (6\%), sulfate (20.34\%) and total sugars $(30.02 \%)$ as reinforced by IMA $(14.45 \%)$ calculated from the chromatogram (Figure 1).

As already revealed for the Halymenia sp. crude extract, the protease treatment confirmed its efficiency for algal protein digestion to improve the purity of the SPs based on Rodrigues et al. (2016). It allowed us also to confirm that the SPs fractions from this seaweed exhibited to be of heterogeneous composition as revealed by total sugars/sulfate ratio (Table 1), as typical characteristics of SPs from seaweeds (Pomin \& Mourão, 2008; Quinderé et al., 2014; Mourão, 2015). Taking with literature data, the observed differences among the relative number of fractions during comparisons with the study of Rodrigues et al. (2012) could be attributed to the biosynthesis of the algal concerning its cell-wall SPs in the medium where it was collected as a result of the ecophysiological growth conditions (Cardozo et al., 2007; Prajapati, Maheriya, Jani \& Solanki, 2014).

\section{PHYSICAL-CHEMICAL CHARACTERIZATION BY ELECTROPHORETIC TECHNIQUES ASSOCIATED WITH TOLUIDINE BLUE AND STAINS-ALL WOULD ALSO REVEAL NONSPS}

In order to visualize the presence of complex glycans in the Halymenia sp. SPs preparations, the physicalchemical features by agarose gel and polyacrylamide gel electrophoreses were also evaluated in the current study. Comparing between procedures, the analyses revealed the occurrence of complex glycans for all the examined polymer samples, after sequential staining with toluidine blue and stains-all with basis on standard glycosaminoglycans (Figure 2) (Volpi \& Maccari, 2002).

Staining of the Halymenia sp. SPs, after their migration by both electrophoretic techniques, with the cationic dye toluidine blue revealed metachromasy due to interaction with the negatively charged groups $(\mathrm{S}=\mathrm{O})$ present in the structural composition of the glycans (Leite et al., 1998; Rodrigues, Torres, Alencar, Sampaio \& Farias, 2009a; Rodrigues et al., 2016). For the system in agarose gel made of 1,3diaminopropane buffer (Figure 2Aa), the electrophoretic mobility of the crude extract and its fractions revealed single component, coincident and strong metachromasy co-migrating as HS (Rodrigues, Vanderlei, Quinderé, Fontes \& Benevides, 2010). Except fraction F III, which it was highly polydisperse exhibiting relatively low metachromatic property within all the analyzed fractions, showing mobility close to DS (Rodrigues et al., 2011). 


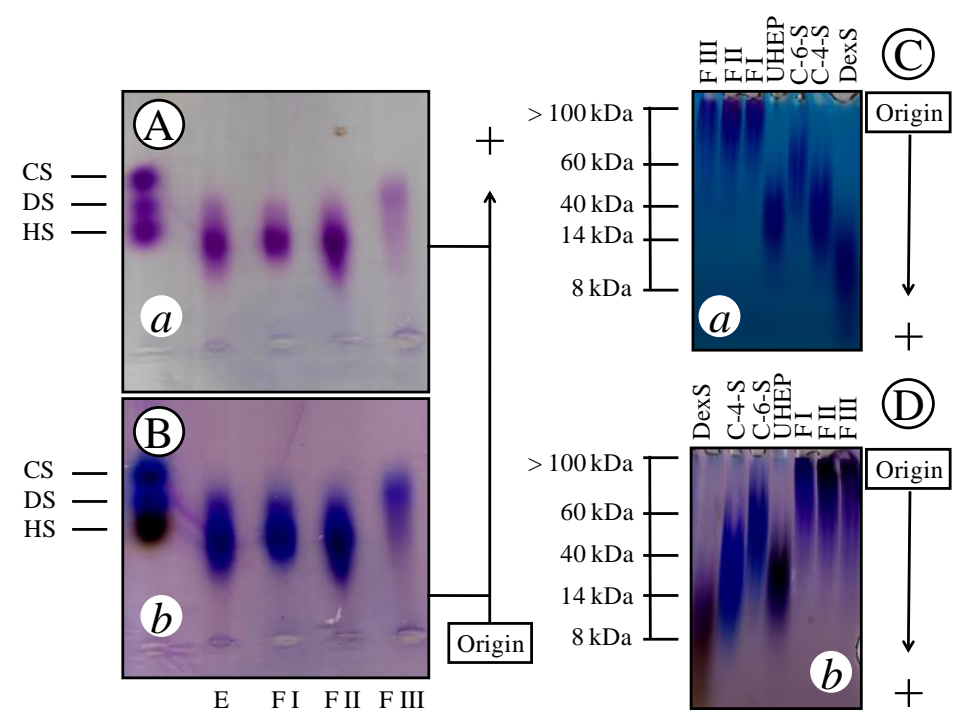

Figure 2. Electrophoreses in agarose gel (A and B) and polyacrylamide (C and D) gel of the SPs isolated from the red seaweed Halymenia spp.. Extract and fractions (F I, F II and F III) and standard glycosaminoglycan chondroitin-4sulfate (C-4-S, $40 \mathrm{kDa})$, chondroitin-6-sulfate (C-6-S, $60 \mathrm{kDa})$, dextran sulfate (DexS, $8 \mathrm{kDa})$ and unfractionated heparin (UHEP, $14 \mathrm{kDa}$ ) present on gels were stained with $0.1 \%$ toluidine blue $(a)$ or Stains-All $(b)$.

As seen, the degree of charge density and the polydispersion of the Halymenia sp. SPs did not show the expected (Rodrigues et al., 2012) because of a different structural conformation or charge/mass ration of these compounds (Dietrich \& Dietrich, 1976) examined in this study, as verified by staining pattern of the polysaccharides individualized according to stepwise of $\mathrm{NaCl}$ (Figures 1 and 2Aa) in coherency with their respective sulfate contents (Table 1), which supported the agarose analysis (Rodrigues, Vanderlei, Quinderé, Fontes \& Benevides, 2010). On the basis these current findings, studies on the focus molecular deserve be better interpreted in chemotaxonomy of the Halymenia genus (Lail, Li \& Li, 1994; $\quad$ Rodrigues \& Farias, 2009).

Regarding the polyacrylamide procedure (Figure 2Ca), the samples of high molecular weight SPs fractions (> $100 \mathrm{kDa}$ ) revealed as heterogeneous systems similar to other SPs from algae (Pomin, 2012; Mourão, 2015; Rodrigues et al., 2017), although presenting certain electrophoretic mobilities with the standard glycosaminoglycan on a comparative basis; therefore, requiring a more refined study regarding their molecular masses by chromatographic techniques (Fenoradosoa et al., 2009; Prajapati, Maheriya, Jani \& Solanki, 2014).

The combined treatment with toluidine blue and stains-all considerably improved the visualization of complex polysaccharides (crude extract, fractions and standards) on both agarose and polyacrylamide gels. As indicated in figures $2 \mathrm{Bb}$ and $2 \mathrm{Db}$, especially for the $1 \mathrm{M} \mathrm{NaCl}$ fraction (F III) showing lowest yield value (Table 1), it was revealed glycans (mainly nonSPs) at a level greater than after staining with toluidine blue alone from the polysaccharidic preparations (Figures 2Aa and 2Ca) and the formation of these stable complexes could involve the spatial arrangement of the polysaccharides (Volpi \& Maccari, 2002).

Studies on the determination of the main structural features of complex SPs from Halymenia species revealed highly pyruvylated polysaccharides predominantly composed of 3-linked $\beta$-D-galactopyranoses and 4-linked $\alpha$-D/L-galactopyranoses having minor amounts of 3,6-anhydrogalactopyranoses (Lail, $\mathrm{Li} \& \mathrm{Li}$, 1994; Fenoradosoa et al., 2009). Thermal behavior analysis implied to conformational changes, mechanisms of intermolecular aggregations and intramolecular reorganizations of the polysaccharide

(Lail, Li \& Li, 1994).

On a basis of application, the combined methodology using toluidine blue and stains-all staining would suggest us to examine the course of extraction of biotechnologically-important algae SPs to quality control of complex carbohydrates-based products (Prajapati, Maheriya, Jani \& Solanki, 2014; Paula et al., 2015) in the direct visualization of polymeric contaminants, presents even in small quantities, with great sensitivity, such as carboxylated in glycans (Volpi \& Maccari, 2002). 
THE DETECTION LIMIT FOR THE DETERMINATION OF ANTICOAGULANT POTENTIAL (HALYMENIA SP. SPS) IS AT LEVEL GREATER USING A TG SYSTEM THAN CLASSICAL APTT AND PT ASSAYS

It was initially measured both Halymenia sp. SPs APTT and PT effects in normal human plasma treated with different sample concentrations using UHEP $\left(193 \mathrm{IU} \mathrm{mg}^{-1}\right)$ as a reference. APTT assay showed that extract and fractions displayed intrinsic coagulation pathway inhibitions (concentration-dependent) since the values were extended compared with those of the control without SPs $(33.37 \pm 0.13 \mathrm{~s})(\mathrm{p}<0.05)$ (Figure 3A) (Rodrigues, Torres, Alencar, Sampaio \& Farias, 2009a; Silva et al., 2010; Amorim, Rodrigues, Holanda, Mourão \& Benevides, 2011).

The anticoagulant profiles confirmed those reported by Rodrigues et al. (2012) as for SPs fractions isolated from Halymenia sp.; likewise, higher concentrations of algal SPs were required to double APTT vs. control, whereas the UHEP APTT values still revealed anticoagulation in a minimum concentration of 2.5 $\mu \mathrm{g} \mathrm{mL}^{-1}(38.80 \pm 0.14 \mathrm{~s})$, as expected using the respective coagulation model (Rodrigues et al., 2017; Salles et al., 2017).

The actions of the crude extract was about 2.48 -fold more potent $\left(19.6 \mathrm{IU} \mathrm{mg}^{-1}\right)$ than fraction F II $\quad(7.88$ $\mathrm{IU} \mathrm{mg} \mathrm{m}^{-1}$ ), which contained highest level of sulfate and total sugars/sulfate ratio among the fractions (Table 1 and Figure 2A). This evidenced that the actions of these molecules on APTT test were linked to the degree of sulfation and charge density of the SPs since the fractions F I and F III had comparatively lower APTT effects (3.96 and $2.04 \mathrm{IU} \mathrm{mg}^{-1}$, respectively) ( $\mathrm{p}<0.05$ ) based on control sample without SPs (Rodrigues et al., 2011; Pomin, 2012; Mourão, 2015).
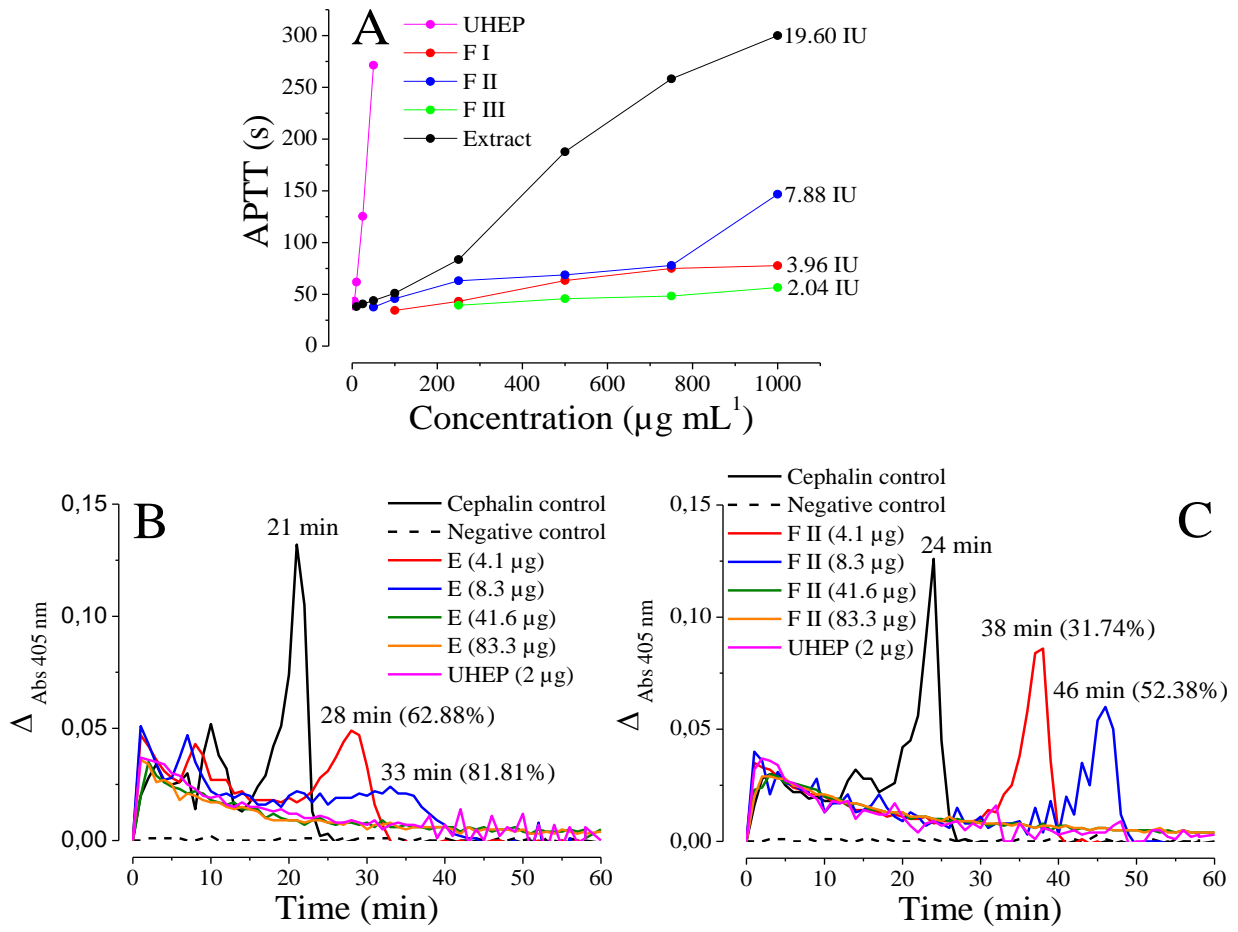

Figure 3. Effect of different concentrations of SPs from the red seaweed Halymenia sp. on APTT (A) and on cephalintriggered TG in 60-fold diluted human plasma using chromogenic method by a continuous detection system after 60 min at $37^{\circ} \mathrm{C}$ (extract - E (B) and fraction - F II (C)).

These significant differences could also be the result of the variable presence of carboxylated groups in the chemical structures of these glycans (Figures 2B and D), leading to a relevant impact on their anticoagulant effects (Pomin \& Mourão, 2008). No clot inhibition was recorded in the PT assay when plasma was treated with crude extract and fractions $\left(1 \mathrm{mg} \mathrm{mL}^{-1}\right)$ compared with UHEP (data not shown), suggesting that the SPs from Halymenia sp. did not affect the extrinsic coagulation pathway factors (Rodrigues, Vanderlei, Quinderé, Fontes \& Benevides, 2010; Dantas-Santos et al., 2012).

Since the extract and fraction F II had higher anticoagulant effects (Figure 3A), they were further analyzed on an in vitro TG continuous system using 60-fold diluted human plasma to examine their in vitro anticoagulant dynamics because the limited values proved by APTT and PT methods

(Castoldi 
\& Rosing, 2011).

Thrombin formed in plasma after stimulation by cephalin or thromboplastin was continually recorded for $60 \mathrm{~min}$ at $37^{\circ} \mathrm{C}$ and the inhibitory potency of TG by Halymenia sp. SPs added to plasma was determined by PTh and TPeak (Rodrigues et al., 2016). Both extract and fraction F II concentration-dependently decreased intrinsic pathway TG and their effects are shown in figures 3B and 3C, respectively, as observed by the maximum absorbance of amydolytic activity of thrombin in control plasma in vitro that decayed until a plateau was reached at 21-24 min of TPeak (Mourão et al., 2001; Rodrigues et al., 2016; Salles et al., 2017).

Higher concentrations of Halymenia sp. SPs than that of UHEP on weight basis were required to achieve the total inactivation of TG under our experimental conditions as observed by PTh and TPeak parameters, where an amount of SPs at least 20-fold higher than UHEP was used, similar to other marine SPs displaying in vitro TG inhibition (Nishiro, Fukuda, Nagumo, Fujihara \& Kaji, 1999; Mourão et al., 2001; Rodrigues et al., 2017). Results also indicated that the algal SPs preferentially inhibited the TG induced by cephalin than that after extrinsic one (data not shown); therefore, exhibiting differential results on both coagulation pathways to prevent thrombin formation in vitro (Nishiro, Fukuda, Nagumo, Fujihara \& Kaji, 1999). As expected, UHEP (at low amounts) completely suppressed TG because it has antithrombin-binding pentasaccharide sequence (Nader et al., 2001) with ability to inhibit thrombin activity on both pathways in plasma (Rodrigues et al., 2017; Salles et al., 2017).

The anticoagulant mechanism of the UHEP does not occur in other SPs-rich sources to displays inhibitory action on the blood coagulation by antithrombin, and by preventing the formation of the factor $\mathrm{X}$ - and prothrombin-activating complexes (Pomin, 2012; Mourão, 2015). Amorim, Rodrigues, Holanda, Mourão \& Benevides (2011) revealed that a crude SP extracted from the red seaweed Halymenia floresia showed heparin cofactor II-mediated thrombin inhibition. SPs from seaweeds have anticoagulant mechanisms distinct from that of UHEP leading to differential levels of action on the coagulation according to their structures (Glauser et al., 2009; Pomin, 2012; Quinderé et al., 2014). Thus, a more refined analysis of the Halymenia sp. SPs was performed here using a TG method than conventional APTT and PT tests, which are of limited values to reflect the initiation phase of coagulation (Castoldi \& Rosing, 2011).

In this study, crude extract and fraction F II exerted inhibitions of TG by intrinsic pathway positively related with the sulfation pattern of the SPs (Table 1) contrasting with others studies that suggested stereospecific features of the SPs to modify TG (Rodrigues et al., 2017; Salles et al., 2017). This role induced more than 50\% inhibition of TG in Halymenia sp. crude extract-treated plasma even at concentrations of 4.1 and $8.3 \mu \mathrm{g}$, but not in terms of their molecular mass distribution since the chemical structures of the glycans were not modified after proteolytic extraction as verified by polyacrylamide analysis (Figures 2C and 2D) and helped in solubility of the SPs for use in the coagulation assays (Rodrigues et al., 2017; Salles et al., 2017). A significant reduction in the molecular size of the marine glycans could lead to a plasma TG differential inhibition response level (Rodrigues et al., 2016).

Overall, our observations suggested like carrageenans (kappa, iota and lambda)-type algae SPs that show mechanism of action via thrombin inhibition dependent on the degree of sulfation (Cardozo et al., 2007; Prajapati, Maheriya, Jani \& Solanki, 2014). These three types of co-polymers differ at level of sulfate groups on their structures, having positive impact on their anticoagulant actions, when analyzed by classical APTT assay (Silva et al., 2010). Algae of the genus Halymenia are sources in lambda-type carrageenan molecules (Lail, Li \& Li, 1994; Fenoradosoa et al., 2009), a chemical class that has potential as food additives due to its pronounced rheological properties (Prajapati, Maheriya, Jani \& Solanki, 2014). On a biotechnological perspective, studies focusing on the structure-function relationships of the Halymenia sp. SPs are still required on the blood coagulation system.

\section{Conclusion}

The red seaweed Halymenia sp. changes its polysaccharide content depending on the collection period, expressing complex glycans of high molecular mass (>100 kDa) capable of more accurately modulating a thrombin generation model in 60-fold diluted human plasma than classical coagulation methods, although with lesser inhibitory potential than unfractionated heparin. The potential of Halymenia sp. as an anticoagulant polysaccharides source to prevent thrombosis in vitro is dependent of the sulfation pattern and the use this species for variable applications in industry could be better recognized in studies future. 


\section{References}

Amorim, R. C. N., Rodrigues, J. A. G., Holanda, M. L., Mourão, P. A. S. \& Benevides, N. M. B. (2011). Anticoagulant properties of a crude sulfated polysaccharide from the red marine alga Halymenia floresia (Clemente) C. Agardh. Acta Sci. Bil. Sci., 33(2): 255-261.

Aquino, R.S., Landeira-Fernandez, A.M., Valente, A.P., Andrade, I.R. \& Mourão, P.A.S. (2005). Occurrence of sulfated galactans in marine angiosperms: evolutionary implications. Glyc., 5(1): 11-20.

Bradford, M. M. (1976). A rapid and sensitive method for the quantification of microgram quantities of protein utilizing the principle of protein-dye binding. Anal. Biochem., 72(1-2): 248-254.

Cardozo, K. H. M., Guaratini, T., Barros, M. P., Falcão, V. R., Tonon, A. P., Lopes, N. P., Campos, S., Torres, M. A., Souza, A. O. \& Pinto, E. (2007). Metabolites from algae with economical impact. Comp. Biochem. Physiol. Part C-Toxicol. Pharmacol., 146(102): 60-78.

Chang, C. W., Lur, H. S., Lu, M. K. \& Cheng, J. J. (2013). Sulfated polysaccharides of Amillariella mellea and their anti-inflammatory activities via NF-kB suppression. Food Res. Inter., 54(1): 239-245.

Castoldi, E. \& Rosing J. (2011). Thrombin generation tests. Throm. Res., 127(suppl.3): S21-S25.

Dantas-Santos, N., Gomes, D. L., Costa, L. S., Cordeiro, S. L., Costa, M. S. S. P., Trindade, E. S., Chavichiolo, C. R., Scortecci, K. C., Leite, E. L. \& Rocha, H. A. O. (2012). Freschwater plants synthesize sulfated polysaccharides: Heterogalactans from water hycinth (Eicchornia crassipes). Inter. J. Mol. Sci., 13(1): 961-976.

Dietrich, C. P. \& Dietrich, S. M. C. (1976). Electrophoretic behaviour of acidic mucopolysaccharides in diamine buffers. Anal. Biochem., 70(2): 645-647.

Dodgson, K. S. \& Price, R. G. (1962). A note on the determination of the ester sulfate content of sulfated polysaccharides. Biochem. J., 84(1): 106-110.

Dubois, M., Gilles, K. A., Hamilton, J. K., Rebers, P. A. \& Smith, F. (1956). Colorimetric method for determination of sugars and related substances. Anal. Chem., 28(3): 350-356.

Farndale, R. W., Buttle, D. J. \& Barrett, A. J. (1986). Improved quantitation and discrimination of sulphated glycosaminoglycans by use of dimethylmethylene blue. Biochim. Biophys. Acta, 883(2): 173-177.

Fenoradosoa, T. A., Delattre, C., Laroche, C., Wadouachi, A., Dulong, V., Picton, L. ... Michaud, P. (2009). Highly sulphated galactan from Halymenia durvillei (Halymeniales, Rhodophyta), a red seaweed of Madagascar marine coasts. Inter. J. Biol. Macromol., 45(2): 140-145.

Glauser, B. F., Rezende, R. M., Melo, F. R., Pereira, M. S., Fransischetti, I. M. B., Monteiro, R. Q., Rezaie, A. R. \& Mourão, P. A. S. (2009). Anticoagulant activity of a sulfated: Serpin-independent effect and specific interaction with factor Xa. Throm. Haem., 102(6): 1183-1193.

Kloareg, B. \& Quatrano, R. S. (1988). Structure of the cell wall of marine algae and ecophysiological functions of matrix polysaccharides. Ocean. Mar. Biol. Ann. Rev., 26(1): 259-315.

Lail, M. F., Li, C. F. \& Li, C. Y. (1994). Characterization and thermal behavior of six sulphated polysaccharides from seaweeds. Food Hydrocoll., 8(3-4): 215-232.

Leite, E. L., Medeiros, M. G. L., Rocha,H. A. O., Farias, G. G. M., Silva, L. F., Chavante, S. F., Abreu, L. D., Dietrich, C. P. \& Nader, H. B. (1998). Structure and pharmacological activities of a sulfated xylofucoglucuronan from the alga Spatoglossum schröederi. Plant Sci., 132(2): 215-228.

Mourão, P. A. S., Boisson-Vidal, C., Tapon-Bretaudière, J., Drouet, B., Bros, A. \& Fischer, A. M. (2001). Inactivation of thrombin by a fucosylated chondroitin sulfate from Echinoderm. Throm. Res., 102(2): 167-176.

Mourão, P. A. S. (2015). Perspective on the use of sulfated polysaccharides from marine organisms as a source of new antithrombotic drugs. Mar. Drugs, 13(5): 2770-2784.

Nader, H. B., Pinhal, M. A. S., Baú, E. C., Castro, R. A. B., Medeiros, G. F., Chavante, S. F., Leite, E. L., Trindade, E. S., Shinjol, S. K., Rocha, H. A. O., Tersariol, I. L. S., Mendes, A. \& Dietrich, C. P. (2001). Development of new heparin-like compounds and other antithrombotic drugs and their interactions with vascular endothelial cells. Braz. J. Med. Biol. Res., 34(6): 699-709.

Nishino, T., Fukuda, A., Nagumo, T., Fujihara, M. \& Kaji, E. (1999). Inhibition of the generation of thrombin and factor Xa by a fucoidan from the brown seaweed Ecklonia kurome. Throm. Res., 96(1): 37-49.

Paula, G. A., Benevides, N. M. B., Cunha, A. P., Oliveira, A. V., Pinto, A. M. B., Morais, J. P. S. \& Azeredo, H. M. C. (2015). Development and characterization of edible films from mixtures of $\kappa$-carrageenan, $1-$ carrageenan, and alginate. Food Hydrocoll., 47(1): 140-145. 
Acta of Fisheries and Aquatic Resources

Pomin, V. H. \& Mourão, P. A. S. (2008). Structure, biology, evolution, and medical importance of sulfated fucans and galactans. Glycobiol., 18(12): 1016-1027.

Pomin, V. H. (2012). Fucanomis and galactanomics: Current status in drug discovery, mechanisms of action and role of the well-defined structures. Biochim. Biophys. Acta, 1820(12): 1971-1979.

Prajapati, V. D., Maheriya, P. M., Jani, G. K. \& Solanki, H. K. (2014). Carrageenan: A natural seaweed polysaccharide and its applications. Carbohydr. Polym., 105(25): 97-112.

Quinderé, A. L. G., Santos, G. R. C., Oliveira, N. M. C. G., Glauser, B. F.; Fontes, B. P., Queiroz, I. N. L., Benevides, N. M. B. \& Mourão, P. A. S. (2014). Is the antithrombotic effect of sulfated galactans independent of serpins? J. Throm. Haem., 12(1): 43-53.

Rodrigues, J. A. G., Torres, V. M., Alencar, D. B., Sampaio, A. H. \& Farias, W. R. L. (2009a). Extração e atividade anticoagulante dos polissacarídeos sulfatados da alga marinha vermelha Halymenia pseudofloresia. Rev.Ciên. Agron., 40(2): 224-231.

Rodrigues, J. A. G., Júnior, J. S., Lourenço, J. A., Lima, P. C. W. C. \& Farias, W. R. L. (2009b). Cultivo de camarões tratados com polissacarídeos sulfatados da rodofícea Halymenia pseudofloresia mediante uma estratégia profilática. Rev. Ciên. Agron., 40(1): 71-78.

Rodrigues, J. A. G. \& Farias, W. R. L. (2009). Avaliação comparativa dos polissacarídeos sulfatados extraídos de rodofíceas Halymenia spp.: ferramenta taxonômica para algas? Rev. Bras. Eng. de Pesca, 4(1): 7-20.

Rodrigues, J. A. G., Vanderlei, E. S. O., Quinderé, A. L. G., Fontes, B. P. \& Benevides, N. M. B. (2010). Polissacarídeos sulfatados isolados das clorofíceas Caulerpa racemosa e Caulerpa cupressoides extração, fracionamento e atividade anticoagulante. Acta Sci. Biol. Sci., 32(2): 113-120.

Rodrigues, J. A. G., Queiroz, I. N. L., Bessa, E. F., Coura, C. O., Amorim, R. C. N. \& Benevides, N. M. B. (2011). Anticoagulant activity of sulfated polysaccharides fractions from an aqueous extract obtained from the red seaweed Halymenia floresia (Clemente) C. Agardh. Acta Sci. Technol., 33(4): 371-378.

Rodrigues, J. A. G., Vanderlei, E. S. O., Quinderé, A. L. G., Queiroz, I. N. L., Bessa, E. F. \& Benevides, N. M. B. (2012). Analysis of two drying methods on the yield and activity of sulfated polysaccharides extracted from Halymenia sp. (Rhodophyceae). Acta Sci. Biol. Sci., 34(1): 5-11.

Rodrigues, J. A. G., Vanderlei, E. S. O., Silva, L. M. C. M., Araújo, I. W. F., Queiroz, I. N. L., Paula, G. A., Abreu, T. M., Ribeiro, N. A., Bezerra, M. M., Chaves, H. V., Lima, V., Jorge, R. J. B., Monteiro, H. S. A., Leite, E. L. \& Benevides, N. M. B. (2012). Antinociceptive and anti-inflammatory activities of a sulfated polysaccharide isolated from the green seaweed Caulerpa cupressoides. Pharmacol. Rep., 64(2): 282-292.

Rodrigues, J. A. G., Queiroz, I. N. L., Quinderé, A. L. G., Benevides, N. M. B., Tovar, A. M. F. \& Mourão, P. A. S. (2016). Mild-acid hydrolysis of a native polysulfated fraction from Acanthophora muscoides generates sulfated oligosaccharides displaying in vitro thrombin generation inhibition. Acta Sci. Biol. Sci., 38(1): 7-15.

Rodrigues, J. A. G., Barcellos, P. G., Salles, T. C., Benevides, N. M. B., Tovar, A. M. F. \& Mourão, P. A. S. (2017). In vitro inhibition of thrombin generation by sulfated polysaccharides from the tropical red seaweed Gracilaria birdiae Plastino \& Oliveira. Acta Fish. Aquat. Res., 5(1): 22-32.

Salles, T. C., Rodrigues, J. A. G., Barcellos, P. G., Amaral, G. F., Araújo, I. W. F. \& Mourão, P. A. S. (2017). Inhibition of thrombin generation by dermatan sulfate isolated from the skin of Oreochromis niloticus, Rev. Bras. Ciên. Agrár., 12(1): 98-104.

Silva, F. R. F., Dore, C. M. P. G., Marques, C. T., Nascimento, M. S., Benevides, N. M. B., Rocha, H. A. O.; Chavante, S. F. \& Leite, E. L. (2010). Anticoagulant activity, paw edema and pleurisy induced carrageenan: Action of major types of commercial carrageenans. Carbohydr. Polym., 79(1): 29-33.

Volpi, N. \& Maccari, F. (2002). Detection of submicrogram quantities of glycosaminoglycans on agarose gels by sequential staining with toluidine blue and Stains-All. Electroph., 23(24): 4060-4066.

Wang, L., Wang, X., Wu, H. \& Liu, R. (2014). Overview on biological activities and molecular characteristics of sulfated polysaccharides from marine green algae in recent years. Mar. Drugs, 12(9): 4984-5020.

Zhang, Z., Till, S., Jiang, C., Knappe, S., Reutterer, S., Scheiflinger, F., Szabo, C. M. \& Dockai, M. (2014). Structure-activity relationship of the pro- and anticoagulant effects of Fucus vesiculosus fucoidan. Throm. Haem., 111(3): 429-437. 